\title{
Fabricating the Thanatopolitical Body in Rodrigo Rey Rosa's Cárcel de árboles
}

\author{
Lucy Bollington, University of Cambridge
}

\begin{abstract}
In the biopolitical horizon that characterizes modernity, the physician and the scientist move in the no-man's-land into which at one point the sovereign alone could penetrate
\end{abstract}

---Giorgio Agamben, Homo Sacer (1998: 159)

To arrive at the deepest truth about a body, medical science is forced to insinuate itself into the same cut that etched death into the body, and then redouble it

---Roberto Esposito, Third Person (2012: 22)

What techniques characterise the sovereign power to 'make die' when it appears in the modern biopolitical and techno-scientific age? And how is the human body invested with and inscribed by destructive power? These questions implicitly connect Guatemalan author Rodrigo Rey Rosa's first novella Cárcel de árboles with the thanatopolitical or necropolitical extensions of Michel Foucault's thought advanced by Giorgio Agamben, Roberto Esposito and Achille Mbembe. In what follows, I place Cárcel de árboles in dialogue with thanatopolitical philosophy in order to bring into focus Rey Rosa's portrayal of the ways in which destructive power fabricates and disassembles the human body. My analysis focuses on four interrelated themes: a) I begin by discussing the novella's central prison camp and the forms of disciplinary power, control and thanatopolitics that operate in this space; b) I then examine the importance of medical science in the novella's portrayal of power and embodiment; c) next, I trace out the ways in which language and textuality intersect with the body in Rey Rosa's novella, making particular recourse to Giorgio Agamben's work on testimony and the ethics of 'impotentiality'; d) I end by discussing the body's relationship to the broader non-human landscape, and consider the extent to which this human/ non-human relationship provides a conceptual opportunity for resistance to the thanatopolitical fabrication of the body 
that is otherwise underway in the text. Over the course of this analysis, I argue that Rey Rosa's conceptual and self-reflexive portrayal of the body raises important political, aesthetic and ethical questions about the production and deconstruction of the 'human' in the modern biopolitical age.

Rey Rosa's Cárcel de árboles tells the story of a secret experiment carried out by Dr. Pelcari, and supported by the military and the State. The novella's internal cartography locates Dr. Pelcari's secret prison camp in the Guatemalan jungle, on the edge of the Blue River and on the border of Gallon Jug, Belize. Through a complex set of medical interventions into the larynxes and brains of her 'subjects', Dr. Pelcari creates an army of thousands of men who can be made to work and fight at the whims of the person in charge of her invention's central computer. The novella focuses on the coming-to-consciousness and short-lived escapes of two prisoners who are known as 'YU' (henceforth, YU1 and YU2). Dr. Pelcari gives her prisoners syllabic names (such as 'YU' or 'ZU') that correspond to their spatial position within the greater network of her techno-scientific experiment and which represent the only sound they are capable of making. Following an unexpected plane crash in the forest, YU1 discovers a pencil and paper and begins to write and, through the act of writing, to think. YU1 and YU2 are able to communicate through their written notes and to piece together information about their surroundings that enables them to escape. Both YUs leave the prison by following the Blue River, yet they die under suspicious circumstances either before or shortly after they arrive in Belize. The novella ends when Dr. Pelcari is forced to destroy all the evidence of her experiment for fear that the escaped YUs would lead to the discovery of her secret prison. Dr. Pelcari inserts the final order into her computer, and the prisoners kill the guards, their dogs, and implicitly, themselves. 
The subtle internal geography of the novella works to tie the narrative to Guatemala's recent history, a 'civil war' that lasted over three decades, claiming the lives of an estimated 200,000-300,000 people and displacing up to 1.5 million others. The Commission for Historical Clarification (La Comisión para el Esclarecimiento Histórico - CEH), which documented the atrocities of the 'civil war', discovered that forces connected with the State were responsible for the vast amount of the violence. The State, which frequently acted outside of the law (CEH, 1999: 31), was found to have committed over $90 \%$ of the murders and forced disappearances, and the vast majority of the instances of torture and other abuses of human rights (25). The State operated on a counterinsurgency pretext with the alleged aim of quashing rebelling 'subversives', 'enemies' and 'communists'. However, the $\mathrm{CEH}$ discovered that the vast majority of the violence was perpetrated against the civilian Mayan population, leading the commission to characterise the conflict as a 'genocide'. The worst of the violence occurred from 1981-1983, when entire villages were burnt to the ground and rural communities were repeatedly terrorised through baroque public displays of torture as part of President Efraín Ríos Montt’s counterinsurgency campaign. Socalled 'model villages' were set up by the military following the destruction of these communities, and those held in these new 'villages' were made to participate in patrols, kidnappings and massacres against supposed 'guerrillas' in their former communities, while also further destroying local crops and materials. As Greg Grandin, Deborah Levenson, and Elizabeth Oglesby write, 'through the civil-patrol network, the Guatemalan army inserted itself into the fabric of everyday village life, and this local-level militarisation became one of the most pernicious legacies of the counterinsurgency' (2011: 364). Rey Rosa's novella resonates with aspects of this recent context of violence while also incorporating broader conceptual reflections on the relationship between power and the body. 
Existing scholarship on Cárcel de árboles has advanced some significant claims, which it will be important to review briefly before looking at the novella more closely. Luis Cano situates the novella within the tradition of Latin American literary science fiction, calling attention to the ways in which it reflexively signals its own belonging to this tradition (2012: 401). Cano maps the significant influence of Rubén Darío, Jorge Luis Borges and Adolfo Bioy Casares, noting in particular the thematic similarities between Cárcel de árboles and Bioy Casares' La invención de Morel and Plan de evasion (397-398). It is through this literary genre that Cano interprets the intertextual circulation of medico-scientific discourse within Cárcel de árboles (395). My reading of the novella also recognises the importance of these quotations, but demonstrates the ways they shape the connection between medicine, science and the body that marks biopower and its transformation into thanatopolitics. Critics have also made evocative observations about the relationship between embodiment and textuality in the novella. Andrea Castro, for example, speaks of the textual nature of the scars that mark the prisoners' bodies (2010); while Sergio Villalobos-Ruminott establishes a connection between Rey Rosa and Franz Kafka, describing Cárcel de árboles as a 'suerte de versión guatemalteca de La colonia penitenciaria' (2013: 143). My reading builds on this latter connection indirectly, due to the ways in which Kafka's penal machine relates to Foucault's vision of how power and discourse are inscribed on the body. Judith Butler summarises this parallel succinctly, writing that 'for Foucault, not unlike for Kafka in The Penal Colony, the cultural construction of the body is effected through the figuration of "history" as a writing instrument that produces cultural significations - language through the disfiguration and distortion of the body..' (1989: 603). Metaphorical and literal processes of writing and reading are crucial to Rey Rosa's depiction of deathly embodiment, and to his self-reflexive criticism of its aesthetic treatment, as 
we will see. My approach to these textual processes challenges existing readings of

Cárcel de árboles that emphasise the liberatory potential of writing and reading in Rey Rosa's novella (for example, in Castro: 2010, De la Puente: 2013, and Coello Gutiérrez: 2008).

\section{Power in the Prison Camp}

As the narrative of the novella unfolds, readers are slowly exposed to the spatial arrangement of Dr. Pelcari's secret prison camp. The YUs' writing makes clear that the prisoners are chained to trees, which function as cells of sorts, and suggests that there are 'thirty-six' tunnels of these trees, which converge onto a 'gathering-place' or opening in the centre of the forest. The prisoners' monosyllabic names are inscribed onto the metal shackles that attach them to the trees; YU2 realises that the YUs are called 'YU' 'because we are chained to the tree that corresponds to the 'Y' on the lane marked "U”' (Rey Rosa, 1991: 59). ${ }^{1}$

Rey Rosa's prison of trees is characterised by aspects of the disciplinary power theorised by Michel Foucault in relation to carceral environments. In Discipline and Punish, Foucault traces the rise of a new 'micro-physics' of power during the eighteenth century, which works in 'enclosures' such as prisons, factories, schools, and the barracks. This 'disciplinary power' touches the body indirectly, Foucault explains, accessing its 'forces, their utility and their docility, their distribution and their submission' (1995: 25). A moulding of the body is achieved

\footnotetext{
${ }^{1}$ I have used Paul Bowles' translation of Cárcel de árboles, entitled The Pelcari Project, rather than providing my own translation due to the crucial significance of Bowles to Rey Rosa's writing. Not only is the novella dedicated to Bowles, in interviews Rey Rosa has intimated that he thought of Bowles as both friend and mentor, as an essential interlocutor, and that he often wrote with Bowles in mind as his primary audience. By incorporating Bowles' translation I hope to point to a contextual story that falls outside the scope of the present enquiry. All translations of other sources from Spanish into English are my own.
} 
through techniques such as surveillance, examination, training exercises and the implementation of timetables, diffuse strategies that marshal time and space in order to fabricate the 'docile bodies' of the 'machine-men' and 'proletariats' (242) that were required for the capitalist economy to grow and triumph (221). The bodies of the prisoners in Rey Rosa's prison camp are shaped and militarised through the implementation of such techniques. The spatial layout of the prison facilitates a certain degree of surveillance, given how the tunnels of trees can be perceived from the forest's central opening. Time is also marshalled to mould the prisoners' movements. YU1 reveals, for example, the existence of a strict timetable, commenting that he perceives 'a pattern in the way our days are run. We get up at dawn, when a drum is being beaten. The guards march down the avenues, stopping at the foot of each tree to remove the bolts from the shackles, and hurry us, one after the other, towards a circular open space...' (Rey Rosa, 1991: 28).

Once the prisoners are moved into this opening, they encounter another disciplinary technique: a daily training exercise, or drill of sorts. This drill takes the form of a communal chant, which is instigated by a central computer, and which induces a trance-like state while orders are relayed and received directly within the prisoners' bodies to ensure maximum compliance (Rey Rosa, 1991: 30-31). As YU1 observes, the prisoners' bodies are made docile and malleable through these chants, which 'persuade these - thousand, two thousand? - men that they are only one single thinking man who loves his work and is happy' (53). This quotation resonates with Foucault's argument that disciplinary power functions to combine individual bodies within a productive force that exceeds the potentialities of any of the singular components—-thus, in Rey Rosa's novella the prisoners' bodies are both individually moulded and co-fabricated into a collective body. 
These chants prompt the prisoners to partake in military missions and to engage in manual labour by 'clearing the earth' with their hands to find objects (31). As with Foucault's disciplinary society, the moulding of the body of the soldier is intimately connected with the production of the labour-force, demonstrating the extension of structures of war into the broader arenas of politics and the economy. This intersection of militarism and society also resonates with Guatemalan history. In particular, the chants, as a form of training, are reminiscent of the military's coerced transformation of civilians into paramilitary or patrol forces during the conflict. ${ }^{2}$

Rey Rosa's prison also moves beyond disciplinary power in a number of important ways. Foucault's understanding of the ways in which carceral power shapes human bodies relies on the notion of prison walls, which 'both enable and limit the exercise of carceral logics... [differentiating] social space', as Michael Hardt and Antonio Negri write (2001: 329). In the forest environment of Rey Rosa's novella the prison opens onto the broader jungle terrain, merging with the natural environment. Instead of walls, the prison is cordoned off with 'an almost invisible thread...strung from one tree to another' (Rey Rosa, 991: 32), and attached to bells. This string, the YUs suggest, is easy to elude once they gain consciousness through their writing and slip free of their bonds; thus the role of the carceral wall loses prominence.

Around the time Cárcel de árboles was written, Deleuze observed that since World War II there had been a general 'crisis' in the walled enclosures described by Foucault and suggested that new forms of control that were less bounded in space had emerged. Some of the forms of control Deleuze describes are latent in Dr.

\footnotetext{
2 More broadly, the fluid movement between war and labour that the chants engender reflects the 'military-civil' power structure that characterised Guatemala between the 1960s and 1990s and continues to be one of the lasting traits of the conflict (see Krujit, 2000: 10).
} 
Pelcari's prison. Her experiment relies on a central computer with a 'control' button (Rey Rosa, 1999: 13), in relation to which bodies are affixed in a grid-like formation, and the cybernetic basis of the grid invokes the nascent contours of the dispersive and 'networked' power of the control society, where 'what counts is not the barrier but the computer that tracks each person's position' (Deleuze, 1992: 7). The grid of scars that covers the YUs' heads symbolise the inscription of this new form of networked power onto the body, alluding to the body's fabrication through technological processes. These corporeal markings literalise Hardt and Negri’s sense that in the control society power is exercised 'through machines that directly organise...brains (in communication systems, information networks, etc.' (2001: 23). Moreover, Deleuze highlights ‘instant communication’ coupled with endless training as critical aspects of control (1995: 174), and these characteristics are seen in Rey Rosa's prison chants, within which power is internalised in a manner that overcomes any temporal delay between the espousing and receipt of words.

The intermixture of disciplinary techniques and latent forms of control in Rey Rosa's novella resonates with the transitional economic context of Guatemala in the early 1990s. While discipline is associated with the expansion of industrial capitalism, Deleuze argues that control evolved with capitalism’s mutation away from concentration, production and property and towards a time of speculation, real as opposed to formal subsumption, and the informational economy, where 'what [capitalism] wants to sell is services and what it wants to buy is stock' (1992: 5). At the moment of Cárcel de árboles' publication, Guatemala was involved in an uneven integration into the global economy. From the 1960s onwards, and particularly since the 1980s, the Central American Isthmus underwent a transition into neoliberalism. By contrast to its Central American neighbours, however, Guatemala's transition was reluctant and implemented in 'bits and pieces' (Robinson 103: 2003). On the one 
hand, movements towards deregulation and privatisation in the 1980 s led to the implementation and rapid expansion of the maquiladora industry in Guatemala, in a manner that set the tone for the rest of Central America; on the other hand, the emergent technocratic New Right within Guatemala had to contend with a strong and unified oligarchy of old-guard businessmen who resisted the transnational agenda of neoliberal reform (Robinson 2003). The neoliberal transition that eventually occurred following the peace accords of 1996 was inadvertently facilitated by the militarisation of society in the preceding decades. By the 1990s, the State's destruction and fragmentation of rural peasant communities, economies and forms of organisation forced the former members of these communities 'under the sway of capitalist economic laws' (Robinson, 105). Thus, in the words of William Robinson 'the military's all-out counterinsurgency (what it termed "total war") acted as a perverse midwife to the transnational elite project [of neoliberalism] in Guatemala' (104). ${ }^{3}$ Dr. Pelcari's experiment symbolically convokes the type of social fragmentation that this military destruction provoked, as will become increasingly clear as this article progresses, and in this sense her prison is tied, conceptually, to the context of economic transition.

Returning to the space of the prison, the different techniques used to shape the bodies of the prisoners are undergirded by a constitutive relation to violence and death. On the most basic level, this is because the men in the prison have 'all been condemned to death' by the State, and can be killed with impunity (Rey Rosa, 1991: 15). As such, Rey Rosa's text moves closer to the thanatopolitical and necropolitical developments of Foucault's work that have sought to centralise death when

\footnotetext{
${ }^{3}$ Proceeding according to a slightly different line of thought, Dirk Krujit makes a similar observation about the relationship between militarism and neoliberalism in Guatemala, writing that in many ways it is the military-civil power structure in itself that imbues the nation with 'all the features of a neoliberal state: a neoliberal public sector, a reduced social budget, and, in general, a near absent state sector economy' (2000: 9-10). See Thomas and O’Neill Securing the City for a summary of the specific ways in which neoliberal reform has impacted upon Guatemalan society in the post-war years; see Robinson (2000 and 2003) for a detailed summary of Guatemala's economic transition.
} 
conceptualising power and politics. ${ }^{4}$ Noting the historical connection between the death sentence and medical experimentation, Agamben remarks that 'Like the fence of the camp, the interval between death sentence and exclusion delimits an extratemporal and extraterritorial threshold in which the human body is separated from its normal political status and abandoned, in a state of exception, to the most extreme misfortunes' (1998: 159). In this tradition, Rey Rosa's novella makes use of lives that Agamben describes as 'bare' to denote 'a life that may be killed without the commission of homicide' (159). Following Agamben’s logic, Rey Rosa’s prison camp could be understood as an exemplary biopolitical space, because power is able to confront life directly without the mediating shield provided by political and human rights (Agamben, 171).

Moreover, the tasks that Dr. Pelcari has her prisoners carry out suggest that the forms of discipline and control she instigates do not distinguish between the production of life and death: the men are trained to produce the deaths of others and their own deaths without consciousness or ethical thought. For example, YU2 notes that if the men are deployed to sink a boat, they will carry out these instructions without thought even if it 'costs them their lives' (Rey Rosa, 1991: 60), and the experiment meets its violent end when the prisoners are instructed to execute the

\footnotetext{
${ }^{4}$ For Foucault, the reappearance of the power to 'make die' associated with sovereignty within disciplinary society or biopower is paradoxical, transitional or aberrational, as becomes increasingly clear in Society Must Be Defended. Agamben writes that 'Foucault never brought his insights to bear on what could well have appeared to be the exemplary place of modern biopolitics: the politics of the great totalitarian states of the twentieth century. The inquiry that began with a reconstruction of the grand enfermement in hospitals and prisons did not end with an analysis of the concentration camp', and he attributes Foucault's choice of subject matter to the author's untimely death (1998: 71). Along similar lines, Mbembe writes that 'the notion of biopower is insufficient to account for contemporary forms of subjugation of life to the power of death' (2003: 38-39); while Esposito reflects 'Why does a politics of life always risk being reversed into a work of death? I think I can say, without failing to acknowledge the extraordinary analytic power of his work, that Foucault never fully answered the question' (2008: 8). In my view, Rey Rosa is similarly preoccupied with the relationship between death and power. In what follows, I focus on placing Rey Rosa in dialogue with the thanatopolitical thought of Esposito and Agamben. While Mbembe's thought is extremely useful for tracing the power of death in non-Western contexts given, amongst other things, its movement away from Nazi Germany and the example of the concentration camp, the observations about medicine, language and 'becoming-other' that circulate within thanatopolitical theory have greater resonance with the aspects of embodiment that constitute Rey Rosa's novella.
} 
guards and their dogs, and, implicitly themselves (62). The novella therefore ends with an image of mass death in a secret location.

If Foucault is concerned with the 'fabrication' of docile bodies in his account of disciplinary power (1995: 192), thanatopolitical theory examines contexts in which death has been conceived according to comparable economic, serialised and bureaucratic metaphors as the basis for power and the expansion of capitalism. ${ }^{5}$ The power that characterises the prison environment of Rey Rosa's novella ultimately seems to capture this dual life-death sense of 'fabrication': Dr. Pelcari's experiment combines the disciplinary production of docile life associated with the prison with the logic of disposability linked to the camp in order to mould, coerce and weaponise the human bodies of her prisoners. Her experiment is designed to make the benefactor 'rich' (1991: 16), without regard for whether this wealth is accumulated through violence, experimentation or the labour of bodies that are biologically alive, but politically and socially dead.

\section{Medical Power-Knowledge}

The forms of power that operate in the prison camp work to supplement and enhance a foundational medical intervention into the prisoners' bodies. It is only at

\footnotetext{
${ }^{5}$ Agamben traces the use of the term 'fabrication' to describe the concentration camp in the works of Hannah Arendt and Martin Heidegger (1999: 71-75), and uses the term himself, writing that: in Auschwitz it is no longer possible to distinguish between death and mere decease' between 'death and the fabrication of corpses' (1999: 76). Similar terms were also employed by those who worked in the concentration camps; as Esposito observes: 'Instead of talking about men and women, they referred to pieces (Stücke), replacement parts (Häftlinge), human material (Menschenmaterial), to be loaned (ausleihen), unloaded (abladen), shipped (verschiffen), and eventually, of course, destroyed...' (2012: 61). My use of the term 'fabrication' in the title of this article alludes to the intersection between Foucauldian disciplinary power and these thanatopolitical philosophical and historical descriptions, which emphasise the intermixture of capitalism and violent death. Yet I am also aware of the broader problems with using the term 'fabrication' in relation to death, because, for example, this term inadvertently repeats the linguistic violence of historical spaces of death, and, because it sets up a dichotomy between 'proper' and 'improper', or 'decent' and 'indecent' modes of death (or even collapses this dichotomy, as in Agamben), in a manner that carries its own political and ethical problems.
} 
the end of the novella that readers learn of the exact procedures that Dr. Pelcari has enacted. This knowledge is derived from an autopsy carried out on the deceased body of YU2 by Dr. William Adie in Belize. As he opens up the corpse, Dr. Adie makes notes regarding the 'Bilateral sectioning of the cortex of the limbic system, necessary for long-term or general memory' and the 'Cauterization of thirty-four points in the upward network of the left thalamus, situated in the supposed area of language (Brodman)', for example (Rey Rosa, 1991: 63). Dr. Pelcari's extensive reshaping of the prisoners' bodies works to literalise the disciplinary inscription of power theorised by Foucault, for through these medical procedures power is written directly into the prisoners' anatomy.

Dr. Pelcari's medical interference in the YUs' bodies chimes with Agamben's claim that within biopolitical and thanatopolitical modernity the physician increasingly occupies the space that was once reserved for the sovereign (1998: 159). In their accounts of thanatopolitics, Agamben and Esposito both make the case that this heightened power of the physician is facilitated by advancements in medical technology and scientific knowledge which increasingly enable medical professionals to extend, shorten and control the terms of life and death in a manner that is entangled with politics and that impacts upon the broader social body. In addition to providing an anatomical foundation for the fabrication of the prisoners' bodies, Dr. Pelcari's medical procedures literally and allegorically shape the social body because these procedures target 'memory' and 'language', terms that carry dual medical and socio-political meanings. The doctors' medical procedures produce social fragmentation by cutting individuals off from one another, from themselves and from their pasts, and this fragmentation allows the doctor to conceal and sustain the violence of her experiment by reducing the risk of its revelation. 
In bio- and thanatopolitical theory, the power of the physician to shape the individual and collective body is linked to notions of racism. Foucault suggests that the sovereign power to 'make die' reappears within biopolitics when the health of a given population is seen to be contingent upon the death of certain bodies, and he roots this life-death relationality in the racist eugenic perception that 'the death of the bad race, of the inferior race (or the degenerate, or the abnormal) is something that will make life in general healthier..' (255). Esposito espouses a similar view in his analysis of the auto-immunitary, or self-destructive, drive of the Nazi 'biocracy'. ${ }^{6}$ While theories of degeneracy do not circulate in Rey Rosa's text, medical examination in Cárcel de árboles is subtly undergirded by racism in a manner that resonates with thanatopolitics. For example, the description of Dr. Pelcari's house as 'white and colonial' in the prologue (Rey Rosa, 1991: 12) invokes the unresolved racism that marked Guatemala's foundation and twentieth-century genocide. ${ }^{7}$ This allusion to racism thereby frames the medical experiment as a whole.

The relationship between medical science, power and embodiment is also connected to processes of interpretation and reading in Rey Rosa's novella. This becomes evident if we return to the example of the autopsy carried out by Dr. Adie. The autopsy works to place death in a position of analytical prominence, because the corpse of $\mathrm{YU} 2$ is posited as the most important interpretive key to the events that have taken place. The analytical prominence afforded to the dead body in Rey Rosa's description of the autopsy resonates with Foucault's comments in The Birth of the Clinic about the pivotal work undertaken in the clinic of Xavier Bichat in the early

\footnotetext{
${ }^{6}$ Esposito examines the apparent paradox whereby German medical research was 'one of the most advanced in the world' $(115)^{6}$ at the same time that the medical profession participated directly 'in all of the phases of mass homicide' in the camps (113). Echoing Foucault, Esposito explains that medical advancement and the administration of death occurred because the 'immunity' logic that defines modern politics had turned 'auto-immunitarian' in the face of racist scientific discourses about 'degeneracy', to the effect that killing part of the population was seen as necessary to ensuring the health of the imagined populace; 'in the auto-immunitarian paroxysm of the Nazi vision, generalised homicide is...understood as the instrument for regenerating the German people' (117).

${ }^{7}$ The CEH directly links this colonial context to the rising social and political tensions that provoked the genocidal actions of the State (1999)
} 
1800s. Foucault credits Bichat with transforming the medical gaze by moving it from the external surface of the body to anatomical dissection and thereby introducing a depth that brings with it a new visibility of the body (Gutting, 1989: 128-131). The necropsy of Cárcel de árboles is characterised by this expanded sense of visibility.

Rey Rosa presents this process of obtaining medical and historical knowledge from the corpse as sinister. Drawing on the postmodern Gothic image of the 'mad' scientist, he emphasises Dr. Adie's 'intellectual' eagerness in a manner that calls attention to his lack of sensitivity to the horrors the YUs have suffered: Dr. Adie appears predatory as he sharpens his saw 'to use on the skull' of YU2, and as he works 'for several hours, cursing the heat, the dearth of graphs and of reference books, the lack of assistants, but with growing interest' (Rey Rosa, 1991: 62). Moreover, Dr. Addie is only able to decipher YUq's history, and thus the history of Dr. Pelcari's experiment, by retracing the thanatopolitical markings implemented by Dr. Pelcari to shape the prisoners' bodies. As Andrea Castro notes, the networked scars inscribed on the YUs' heads guide Dr. Adie's corporeal cutting, enabling the doctor 'to glimpse part of what happened to the men' (2010:11). To draw on Esposito's description of Bichat's autopsies, with Dr. Adie Rey Rosa’s readers are confronted with the idea that 'to arrive at the deepest truth about a body, medical science is forced to insinuate itself into the same cut that etched death into the body, and then redouble it' (2012: 22). Put in other words, Dr. Adie's reading of the corpse occurs through a continued destruction that echoes the original thanatopolitical fabrication of the body.

Rey Rosa positions his readers in a similar position to Dr. Adie across the novella: readers are invited to interpret bodies that are either politically or biological dead in order to 'complete' the novella's slowly unfolding narrative through the 
discovery of further information about the experiment. In this sense, the autopsy functions as an allegory for broader processes of writing and reading about the corpse that are central to the novella. Indeed, such a connection between medical examination and the reading process is encouraged in the epigraph that frames the main body of the novella and invites a scientific interpretation of the bodies portrayed. The epigraph reads:

It is possible therefore to think that there exists a neural network peculiar to each fragment of linguistic experience... One is thus led to admit there exists a specific network for the word "mother" (mère) different from the networks for the syllables "me" and "re", and different from the particular networks that represent the phonemes or letters, 'm', 'è', 'r', 'e', , from J. Barbizet and Ph. Duizabo, Neuropsychologie III, $29(19)^{8}$

Dr. Adie's autopsy seems to caution against insensitive, technical or totalising readings of dead bodies that function by retracing and reopening violent wounds. Implicit in this is an awareness of the ways representation, language and interpretation can further supress, desecrate and disabuse the present figure and historical life of the corpse, inadvertently contributing to or reflecting the thanatopolitical fabrication of the body. In this sense, Rey Rosa's novella can be seen to contribute to bio- and thanatopolitical theories by implicitly opening up some of their central concerns to aesthetic and literary concerns.

\section{Literature, Language, Impotentiality}

Dr. Pelcari's medical experiment operates through a scientific and social understanding of the intimate connections between 'words', 'thought' and 'man' (or,

\footnotetext{
${ }^{8}$ This quotation is left in French in both Rey Rosa's novella and Bowles' translation. The original epigraph, in full, reads: 'On peut donc penser qu'il existe un réseau neuronique spécifique pour chacun des fragments d'expérience linguistique, qu'il s'agisse de chaque phonème, de chaque mot qui constituera dans notre cerveau le support matériel, l'engramme, de chacune de ces expériences verbales élémentaires. On est, ainsi, amené à admettre qu'il existe un réseau propre au mot 'mère', différent des réseaux des syllabes 'mè' et 're' eux-mêmes différents des réseaux propres de la représentation des phonèmes ou des lettres 'm', 'è, 'r', 'e”
} 
rather, human) (Rey Rosa, 1991: 13). The doctor considers speech to be the primary means through which the body can be controlled and combined in a workforce with other bodies. The words Dr. Pelcari feeds to the bodies of the prisoners in these recombinations are from high modernist Latin American lettered culture. The parrots the doctor uses in her preliminary experiment are instructed to chant lines from 'Canción de otoño en primavera’ by Rubén Darío (14), and in the epilogue the doctor imagines future human prisoners chanting lines from Jorge Luis Borges' poem 'Ariosto y los árabes' (72). The mechanical reappropriation of two of the most notable Latin American literary figures in a space of death echoes the disillusionment with culture that was expressed following Auschwitz by commentators such as Theodor Adorno and George Steiner. Adorno famously remarked that culture becomes impossible 'garbage' following the barbarism of Auschwitz (2007: 367), and Steiner observed that 'we know now that a man can read Goethe or Rilke in the evening, that he can play Bach and Schubert, and go to his day's work at Auschwitz in the morning' (1998: ix). ${ }^{9}$ High literary culture in Rey Rosa's novella has been similarly reduced to the space of the death camp, which suggests that its humanistic claims have been undermined.

Against this backdrop of lettered culture, which sits uncomfortably in relation to systems of power, Rey Rosa introduces a more popular style of prose that is akin to testimonial writing. The YUs' writings, which document their experiences

\footnotetext{
${ }^{9}$ It is true that Borges in particular occupies a more complex space within Rey Rosa's novella and broader oeuvre than this indictment of his poetry might imply. In her overview of Rey Rosa's work, Alexandra Ortiz Wallner, correctly highlights the 'many connections between Rey Rosa's narrative and Borges's aesthetics and texts' (2013: 136), and Rey Rosa cites Borges' influence in numerous interviews. Rey Rosa has commented that Cárcel de árboles is conceived, in a very conscious way, under the sign of both Borges and Bioy Casares' (Rey Rosa and Durante, 2007: 2), and reflects that 'apart from serving as a kind of literary road map [Borges] directs us toward the best that is in us' (Esposito and Rey Rosa, 2015: 1). Thus, while on the one hand the inclusion of Borges, and Darío, in the doctor's experiments invokes the failure of humanistic culture to ward off destruction and points to its openness to thanatopolitical appropriation; on the other hand the inclusion of these lines seems to also function as a form of intertextual homage to the writer who perfectly invoked the 'mix of cerebral control and physical despair' Rey Rosa seeks to narrate in his depiction of thanatopower (Esposito and Rey Rosa, 2015: 1).
} 
and emotions, constitute a large portion of the overall text of Cárcel de árboles. The novella's performance of testimony can be compared to the conceptual strategy foregrounded in Agamben's Remnants of Auschwitz, which speaks about the concentration camp by giving sustained room to the testimony of survivors. ${ }^{10} \mathrm{By}$ interspersing, and creating a tension between, philosophical reflection and testimony, Agamben explicitly strives to bypass the 'unsayability' impasse that has dominated ethical thinking. Agamben writes that 'To say that Auschwitz is "unsayable" or "incomprehensible" is equivalent to euphemein, to adoring in silence, as one does with a god. Regardless of one's intentions, this contributes to its glory' (1999: 32-33); and he concludes that treating atrocity as 'unsayable', divorcing it completely from language, means 'unconsciously [repeating] the Nazis' gesture' (157). Instead, Agamben engages in the act of 'listening' to the 'essential lacuna' at 'the core' of testimony, as a way of pointing to new forms of ethics (13-14). This lacuna is created by the fact that the survivors, who provide the testimony, did not die in the camps, and were not therefore made speechless (33), and as such these surviving authors 'must in some way submit his every word to the test of an impossibility of speaking' when they speak of the camp (157).

Agamben's theory of language develops from his belief that twentiethcentury linguistic thought did not attend to relationship between language and the non-relational, caught up as it was with a focus on language as 'a system of relations' (Colebrook and Maxwell, 2016: 40). As a consequence, Agamben contends that what needs to be thought is 'language's genesis and its relation to the silent life that it always harbours as an impotentiality' (Colebrook and Maxwell, 41). ${ }^{11}$ For Agamben

\footnotetext{
${ }^{10}$ It is important to note that while Agamben draws on the actual testimonies of historical victims of the Nazi concentration camp, Rey Rosa's narrative is fictional. Thus, while both works are shaped by social contexts of mass death, Rey Rosa's narrative operates at a conceptual distance and does not bear the same direct relation to the event that it evokes.

${ }^{11}$ By contrast to the more recent vitalist, materialist and 'non-human' theories that have developed in opposition to the linguistic thought of post-structuralism, Agamben still
} 
this impotentiality of speech can be clearly seen in the 'Muselmann' of Auschwitz. Agamben explains that the Muselmann (Muslims) was the name given to prisoners in the worst stages of malnutrition and decomposition in the camps, because 'seeing them from afar, one had the impression of seeing Arabs praying' (1999: 43). ${ }^{12}$ For Agamben, the Muselmann is not outside of language, but is marked by having 'a potentiality to speak that is not actualised', by occupying 'a threshold' between speech and silence (Colebrook and Maxwell, 2016: 43). Thus, in Agamben's view, 'the loss of speech...exposes [the Muselmann] as humans in their constitutive capacity not to arrive at their (supposedly) essential humanity' (Colebrook and Maxwell, 44); because 'the human being exists in the fracture between the living being and the speaking being, the inhuman and the human' (Agamben, 1999: 134).

This relation Agamben theorises regarding the possibility and impossibility of speech resonates with the tension that unfolds in Cárcel de árboles. The writing of the YUs is marked by a material context of silence. On the one hand, Dr. Pelcari's experiment literally disenables the capacity for speech, locking the prisoners in a mono-syllabic oral language. Contextually speaking, the notion of silence also refers to direct and indirect forms of censorship; indeed, the $\mathrm{CEH}$ entitled their report on the human rights abuses 'Guatemala memoria del silencio', a title that refers to the fact that during the conflict even 'thinking critically became a dangerous act' and writing about the socio-political character of the nation could lead to 'torture, disappearance and death' (1999: 36). This danger intensified existing barriers to communication that existed due to the specific multi-linguistic fabric of the nation; as Beverley and Zimmerman note, 'a majority or close to a majority of the population of Guatemala is

maintains the primacy of language in relation to the study of (human) life (Colebrook and Maxwell 2016: 35). Rey Rosa's depiction of embodiment similarly combines linguistic primacy with corporeal materiality.

${ }_{12}$ Agamben has received (valid) criticism for his lack of examination of this term (see Colebrook and Maxwell 2016: 44-45). 
made up of non-Spanish-speaking Indian peoples', and 'there are at least twenty-two Indian languages spoken ...' (1990: 145-146).

On the other hand, Rey Rosa's novella is driven by a desire to speak. Dr. Pelcari reveals that YU2 was a '3 1-year old unmarried journalist' when he was imprisoned (Rey Rosa, 1991: 70), and the novella implies that the residual imprint of this past explains the prisoner's persistent impulse to write in the present. For YU1, to write 'means to put memories together' (29), to 'conceive of new ideas' so that 'the shape of my world alters' (36), and the act of writing also works to reveal and challenge the experiment's power structure, making YU1 feel 'superior' to the guards (36). YU1 also suggests that there is something constitutively human about written language; he asks: 'Where do they come from, the words my hands know and which I don't?...it's as if I were to be asked where I come from' (31). Such reflections concerning the opening of the world and subjective existence through language have given rise to readings of the novella that emphasise the 'liberatory' nature of writing. For example, Emiliano Coello Gutiérrez contends that writing carries a 'revolutionary potential' in the novella that is odious for 'whatever form of despotism' (2008: 48), a sentiment that Castro echoes in her reflection that writing enables YU1 to become formed, and to live, as a 'subject' (2010: 9). For me, the act of writing functions as a site in which subjective form is made and unmade and negotiated; a site in which the relational domain of language and subjection is always situated in relation to the non-relational material space of silence and the impersonal, in the sense meant by Agamben.

Agamben suggests that this 'threshold' between the relational and nonrelation occurs within the very structure of testimonial writing:

Testimony takes place where the speechless one makes the speaking one speak and where the one who speaks bears the impossibility of speaking in his own speech, such that the silent and the speaking, the inhuman and the human enter into a zone of indistinction in which it is impossible to establish 
the position of the subject, to identify the "imagined substance" of the "I", and, along with it, the true witness (1999: 120)

The instability of the 'I' that Agamben describes is clearly apparent with the YUs.

At the most basic level, I would argue that this is evident in their syllabic names: though this is never stated in the novella, the name 'YU' is effectively a combination of the Spanish yo(I), and the tú, the familiar other. ${ }^{13}$ 'YU' is therefore neither completely a speaking self nor completely Other. This reworking of personal pronouns becomes more complex once the YUs enter into dialogue with one another, for this dialogue creates a second subjective doubling that already contains an original subjective/onomastic doubling. At the same time, 'YU' is ultimately impersonal and meaningless, and seems to contain the trace of the presence and loss of the human personal pronoun in its very form. In these ways, the YUs' writing resonates with Agamben's observation that 'every testimony is a field of forces incessantly traversed by currents of subjectification and desubjectification' (1999: $121)$.

The importance of Agamben's observations about 'non-speech' and testimony are that they provide the cartography for a new form of ethics that no longer takes an 'actualised' version of the (speaking) human 'person' as its subject. This is why understanding potentiality to mean also impotentiality is a crucial task in resisting the perceived 'dehumanisation' of the thanatopolitical project and its taxonomical exclusions. Agamben allows us to understand 'the human' in more capacious terms as both relational and as s/he who maintains a non-relational relation. Rey Rosa implicitly works within a similar ethical threshold in his depiction of the body and its connection, or non-connection, to language.

\footnotetext{
${ }^{13}$ As I mentioned earlier, in the novella the explanation given for this monosyllabic name is that it corresponds to the prisoner's position within the prison space
} 


\section{Becoming-Forest}

Rey Rosa's extended portrayals of the body's relationship to the natural terrain have not received much attention within criticism on Cárcel de árboles. At a time in which the turn towards the non-human within scholarship is reshaping fields from anthropology to cultural studies, it is timely to ask how these non-human elements might intersect with bio- and thanatopolitical theories of power and the body.

The natural environment is by no means completely outside of Dr. Pelcari's experiment. Indeed, both the trees that function as cells and the parrots that the doctor uses for her preliminary experiment suggest that nature has been instrumentalised within the thanatopolitical matrix. Yet, Rey Rosa suggests that nature also provides a degree of resistance. In the epilogue, for instance, the doctor identifies the centre of a 'cold, clean, grey city' as the ideal place for her invention, not the 'private and secret prison in the tropical forest' that she leaves behind (Rey Rosa, 1991: 72). The aleatory elements of the forest seemingly mean that it cannot be subjected to complete domination.

The natural environment also plays a fundamental role in the basic survival and short-lived escape of the YUs. YU1 merges his body with the environment to avoid being discovered, hiding in the leafy branches of 'his' tree, for example, or concealing his body in the river when the guards' dogs approach (Rey Rosa, 1991: 43). YU2 uses nature to block out the indoctrinating sound of the chant, using the 'sap that oozes from the tree trunk' to block his ears (61). The environment also yields materials that help YU1 to survive until he can gain access to food supplies, in a manner that echoes the recent history of displacement in Guatemala. As Victoria Sanford writes, in the hundreds of testimonies I have taken from massacre survivors, the power of the hunger, thirst, and illness of life in flight from army troops overwhelms even the event of the massacre because life in flight went on for 
years' (2003: 182). Those displaced consumed weeds, bark and roots, and anything else they could find (Sanford, 182), and Rey Rosa's YUs consume similar materials.

Meanings related to the experiment and possible pathways of escape also emerge as the YUs' listen to and watch the natural terrain. For example, YU1 ponders: 'at daybreak...the flock of red birds flew by above the tops of the trees. The great noise made by the flock, not the sharp sound made by one bird, does this have a meaning' (Rey Rosa, 1991: 44); while also listening to 'the sound of the water' and watching the 'full moon' (31) as he pieces together the coordinates of his environment and plans his escape. The YUs' relationship with nature points towards mechanisms of representation, communication and thought that exceed the human symbolic realm of language in a manner that foreshadows Eduardo Kohn's anthropological insights in How Forests Think: Toward an Anthropology Beyond the Human. Drawing on the linguistic philosophy of Charles Peirce, Kohn locates human symbolic forms of communication within a broader network of indices and icons that are inherent to nonhuman selves as well as humans. Thus for Kohn, plants and animals are constitutively semiotic and they adapt over time to 'represent' their environment through the shape of their forms or bodies. If language in the form of speech is physically limited in the prison camp, Rey Rosa's portrayal of the natural terrain appears to hint towards openings and broader networks of relationality. ${ }^{14}$

Drawing on different but not incomparable theoretical terms, Esposito has suggested that such 'impersonal' relations beyond the human can provide the blueprints for a reworking of thanatopower. In Third Person, Esposito laments the failure of human rights in the decades following Nazism, noting the proliferation of

\footnotetext{
14. The YUs are engaged in a desperate search for meaning, as their written notes demonstrate, and thus appear in some ways to be in a state of 'hyper-semiosis'. In this sense, it is difficult to discern the extent to which they project signs upon the environment, anthropomorphising its properties, and the extent to which the environment's inherent iconicity and indexicality appears independently of, although in relation to, human modalities of thought. The weight Rey Rosa attributes to natural imagery both in Cárcel de árboles, and within his broader oeuvre, would seem to suggest that he makes space for a broader conception of non-human agency in his literature.
} 
other spaces of violence. ${ }^{15}$ For Esposito, the failure of human rights is largely due to its reliance on the category of the 'person'. Esposito argues that in the twentiethcentury thanatopolitics crushed the 'person' through its extreme violence, yet this destruction simultaneously led to the re-emergence of the 'person' within human rights discourses: thus, the category of the person 'took form as an almost obligatory retort to the out-and-out attack it was subjected to' (2012: 5). However, Esposito cautions that the category of the 'person' always works to create a split within human life and pushes other (human) beings towards the status of things (9-10). For Esposito, the impersonal provides a compelling answer to this problematic dichotomy between persons and things: the 'impersonal' is not a direct attack on or negation of the person as such (as in thanatopolitics); the impersonal 'opens' the person up 'to a set of forces that push it beyond its logical, and even grammatical boundaries', effectively destabilising the 'exclusionary dispositif' of personhood (14). Esposito's commitment to a philosophy of impersonality culminates in a reading of Gilles Deleuze. Esposito praises Deleuze's notion of 'becoming-animal', arguing that it points to 'the non-person inscribed in the person, to the person open to what has never been before' (150-151), and comments that 'unlike blood affiliations and racial memberships [becoming-other] brings into relationship completely heterogeneous terms - like a human being, an animal, and a micro-organism; but even a tree, a season and an atmosphere' (150). Becoming-other therefore functions as a mechanism for counteracting thanatopolitical destruction and objectification while simultaneously countering humanitarian responses to thanatopolitics that inadvertently maintain its exclusion on the basis of the 'apparatus' of personhood.

Rey Rosa's novella works along similar lines, ultimately refusing to reinstate the 'person' disassembled by thanatopower, and exploring through its natural

\footnotetext{
${ }^{15}$ Of which the Guatemalan genocide would of course be one notable example.
} 
imagery other networks of (impersonal) relation. Yet Cárcel de árboles also invokes the limits of impersonality. This caution can be discerned in the example of the Blue River through which the YUs escape from the prison camp by following 'the river...to its end, if a river has an end' (Rey Rosa, 1991: 54-55). In his reading of Colombia’s Magdalena River, Rory O’Bryen has reflected on the contradictory dynamics of rivers in the Deleuzean terms employed by Esposito, noting the ways in which rivers 'join the particular to the universal, the finite to the infinite, the flow of life to the sea of death, and time and identity to their respective negations' (2013: 288). Due to this contradictory relationality, O’Bryen cautions that rivers do not always 'enjoy their full deterritorialising potential', even if they 'encourage affiliation across borders, they are also sites where processes of reterritorialisation are most marked' (230). Drawing on O’Bryen's notion of 'becoming river', I would like to suggest that the Blue River of Rey Rosa's text works in a similar manner: the river undermines the borders of the nation State and enables a flow away from the experiment, but at the same time it eventually delivers the prisoners to a reterritorialised site, at the fraught historical interface between Guatemala and Belize, in which the YUs meet their final destruction. In this sense, the becomings opened up by the natural terrain in Rey Rosa's novella do carry a resistant potential in the tradition of the philosophy of impersonality; yet this potential risks circling back towards the spaces of destruction that it emerges from.

\section{Conclusions}

The Sphinx threw herself from a great height when they guessed her riddle --- Borges, quoted in the epilogue of Cárcel de árboles

The 'other-than-human Sphinx whom, despite her inhumanity, we nevertheless regard and to whom we must respond, asks us to question what we think we know 
about the human. And her question reveals something about our answer', writes Kohn (2013: 5). Following a similar logic, Rey Rosa's closing reference to the Sphinx provokes readers to consider the ways in which the arch of embodiment that is taken to be definitive of 'man'16 has been subject to manipulation in Cárcel de árboles, as invasive medical procedures and technological and disciplinary prostheses, which function as thanatological 'canes' of sort, enter into, rework and disassemble the human bodies of the prisoners. The Sphinx's plunge to destruction gains a new meaning in the context of the destructive power that characterises Rey Rosa's text; the reposed question is something like: what 'human' form is enunciated at the moment of death? And how is humanistic culture intermeshed with violence?

Embedded within Rey Rosa's portrayal of embodiment is a confrontation with the category of 'the human' and its relationship to destructive power at an historical time of transition from genocide to neoliberalism in a techno-scientific age. Esposito writes that 'presumed for centuries as what places human beings above the simple common life of other living species (and therefore charged with a political value), humanitas increasingly comes to adhere to its own biological material. But once it is reduced to its pure vital substance and for that reason removed from every juridical-political form, the humanity of man remains necessarily exposed to what both saves and annihilates it' (2008: 4). Rey Rosa depiction of embodiment underlines this biological substance of the human stripped bare and its invokes its proximity to domination, while also pointing towards new forms of relation and non-relation premised on impersonality and impotentiality that may carry the potential to stave off, or resist, the future annihilation encapsulated in the survival of Dr. Pelcari's thanatopolitical control machine as it slouches towards the urban centre.

${ }^{16}$ The Sphinx famously asks Oedipus: 'What goes on four legs in the morning, two legs at noon, and three legs in the evening?' Oedipus' answer is 'Man'. 


\section{Works Cited}

Agamben, Giorgio. 1998. Homo Sacer: Sovereign Power and Bare Life. Translated by Daniel Heller-Roazen. Stanford: Stanford University Press.

Agamben, Giorgio. 1999. Remnants of Auschwitz: The Witness and the Archive. Translated by Daniel Heller-Roazen. New York. Zone Books.

Beverley, John and Marc Zimmerman. 1990. Literature and Politics in Central American Revolutions. Austin: University of Texas Press.

Butler, Judith. 1989. "Foucault and the Paradox of Bodily Inscription." The Journal of Philosophy 86 (11): 601-607

Cano, Luis C. 2012. "Cárcel de árboles, de Rodrigo Rey Rosa, y la meta-cienciaficción.” Revista Iberoamericana LXXVIII (238-239): 389-403

Castro, Andrea. 2010. "Lo monstruoso como proyección pesadillesca de lo conocido en Gorodischer y Rey Rosa”. Lejana: Revista crítica de narrativa breve 1:1-13.

Coello Gutiérrez, Emiliano. 2008. 'La narrativa breve de Rodrigo Rey Rosa: un vuelco a la racionalidad'. Revista pensamiento actual, Universidad de Costa Rica 8 (1011): 54-59.

Colebrook, Clare and Jason Maxwell. 2016. Agamben. Cambridge: Polity Press.

De la Puente, Maximiliano Ignacio. (2008). 'Formas de representar la violencia en algunas escenas de la literatura latinoamericana’. Questión: Revista Especializada en Periodismo y Comunicación 1 (18): 1-9.

Deleuze, Gilles. 1992. "Postscript on the Societies of Control”. October 59: 3-7.

Deleuze, Gilles. 1995. "Control and Becoming" in Negotiations, 1972-1990. New York: Columbia University Press: 169-176.

De Roso, Ezequiel. 2013. 'Evocación, alusión, aplicación: Formas de la ficción en los relatos de Rodrigo Rey Rosa'. Lejana: Revista Crítica de Narrativa Breve 6: 1-12.

Esposito, Roberto. 2008. Bíos: Biopolitics and Philosophy. Translated by Timothy Campbell. London: University of Minnesota Press.

Esposito, Roberto. Third Person: Politics of Life and Philosophy of the Impersonal. Translated by Zakiya Hanafi. Cambridge: Polity Press, 2012.

Foucault, Michel. 1995. Discipline and Punish: The Birth of the Prison. Translated by Alan Sheridan. New York: Vintage Books.

Foucault, Michel. 20o4. Society Must Be Defended. Translated by David Macey.

London: Penguin Books. 
Foucault, Michel. 1976. The Birth of the Clinic: An Archaeology of Medical Perception. Translated by A. M. Sheridan. London: Tavistock Publications Limited.

Grandin, Greg, Deborah T Levenson and Elizabeth Oglesby, eds. 2011. The Guatemala Reader: History, Culture, Politics. Durham, NC: Duke University Press.

Gutting, Gary. 1989. Michel Foucault's Archaeology of Scientific Reason. Cambridge: Cambridge University Press.

Hardt, Michael and Antonio Negri. 2001. Empire. London: Harvard University Press.

Krujit, Dirk. 2000. 'Guatemala's Political Transitions, 1960s-1990s'. International Journal of Political Economy 30 (1): 9-35

Kohn, Eduardo. 2013. How Forests Think: Towards an Anthropology Beyond the Human. Berkeley: University of California Press.

La Comisión para el Esclarecimiento Histórico (CEH).1999. Guatemala memoria del silencio: conclusiones y recomendaciones. Guatemala: la Oficina de Servicios para Proyectos de las Naciones Unidas (UNOPS).

Mbembe, Achille. 2003. "Necropolitics." Translated by Libby Meintjes. Public Culture 15(1): 11-40.

O'Bryen, Rory. 2013. 'Affect, Politics and the Production of the People: Meditations on the Río Magdalena'. Chapt. 9 in Latin American Popular Culture: Politics, Media, Affect, edited by Geoffrey Kantaris and Rory O'Bryen, 227-248. Woodbridge, Suffolk: Tamesis.

Ortiz Wallner, Alexandra. 2013. "Rodrigo Rey Rosa”. In The Contemporary SpanishAmerican Novel: Bolaño and After, edited by Will H. Corral, Juan E. De Castro and Nicholas Birns, 136-141. London: Bloomsbury.

Rey Rosa, Rodrigo. 1992. Cárcel de árboles; El salvador de buques. Barcelona: Seix Barral.

Rey Rosa, Rodrigo. 1991. The Pelcari Project. Translated by Paul Bowles. London: Peter Owen.

Rey Rosa, Rodrigo and Erica Durante. 2007. "Empiezo a escribir escribiendo”: Un arsenal de escritura: Rodrigo Rey Rosa entre Borges y Bioy'. Revue Recto/Verso 2: 18.

Rey Rosa, Rodrigo and Scott Esposito. 2015. 'Interview with Rodrigo Rey Rosa', The White Review < http://www.thewhitereview.org/interviews/interview-withrodrigo-rey-rosa/>

Robinson, William I. Latin America and Global Capitalism: A Critical Globalization Perspective. Baltimore: The Johns Hopkins University Press. 
Robinson, William I. 2003. Transnational Conflicts: Central America, Social Change and Globalization. London: Verso.

Robinson. 2000. "Neoliberalism, the Global Elite, and the Guatemalan Transition: A Critical Macrosocial Analysis". Journal of Interamerican Studies and World Affairs 42 (4): 89-107.

Sanford, Victoria. 2003. Buried Secrets: Truth and Human Rights in Guatemala. New York: Palgrave Macmillan US.

Thomas, Kedron and Kevin Lewis O’Neill. 2011. Securing the City: Neoliberalism, Space, and Insecurity in Postwar Guatemala. Durham: Duke University Press.

Villalobos-Rumnitt, Sergio. 2013. 'Literatura y destrucción: aproximación a la narrativa centroamericana actual', Revista Iberoamericana, LXXIX (242): 131-148. 